\title{
RESPON BIOLOGIS BEBERAPA JENIS PARASITOID PADA LALAT PENGGOROK DAUN Liriomyza huidobrensis BLANCHARD
}

\author{
Sri Wahyuni ${ }^{1}$ dan I Wayan Supartha ${ }^{1}$ \\ Fakultas Pertanian Universitas Flores - NTT', Fakultas Pertanian Universitas Udayana - Bali ${ }^{2}$ \\ sriwahy uni_uniflor@y ahoo.co.id
}

\section{ABSTRACT}

\author{
Biological Responses of Leaf Miner Parasitoids Liriomyza huidobrensis Elancard (Diptera \\ Agromyzidae) \\ This research conducted to know the biological responses of leaf miner parasitoid Liriomyza
} huidobrensis is Hemyptarsenus varicomis Girault (Eulophidae), Opius sp (Braconidae) and Gronotoma micromorpha (Eucoilidae). Three species of parasitoid choosen as substance of research caused of biological agent superiorities. On this research there are some observed that is long life imagoes, preoviposition, oviposition period, after oviposition, The egg-laying rate, fertilization, daily fertilization, mortality and female proportion.

This research was conducted for four month at Ecology Laboratory and Insect Systematics and at the Green House of Pest and Plant Diseases Department, Faculty of Agriculture Udayana University in Denpasar. Used substance of host kidney bean (Vigna sinensis L) host insect ( L. Huidobrensis ) and species of parasitoid (H.varicornis, Opius sp and G.micromorpha) The experiments using randomized complete block design was used in this research

The observed results indicated that betwen three species of parasitoid used H.varicornis has preoviposition period and time after oviposition shortest so that to reproduce generation of H.varicornis faster than G.micromopha and Opius sp. At the mean time the fertilization level, and best female proportion produced of H.varicornis. Mortality on G.micromorpha and O.liriomyzae cause of paralyzing and hostfeeding by H.varicornis. Mortality on G.micromorpha and Opius sp influential to female proportion number that produced that is mortality of female generation caused of paralyzing and host-feeding by $H$. varicornis, So that fertilizing level, parasitisation level and female proportion higher happen if G.micromorpha or Opius sp released after releasing $H$. varicornis

Keywords : G. micromorpha, H. varicornis, Opius sp, L. huidobrensis, biological respons.

\section{PENDAHULUAN}

Liriomyza huidobrensis (Blanchard) (Diptera : Agromyzidae) adalah satu dari 300 spesies Liriomyza yang merupakan serangga hama penting pada berbagai jenis tanaman sayuran dan hias di dunia khususnya pada daerah dataran tinggi (Waterhouse dan Norris, 1987). Gejala serangan serangga hama tersebut berupa bintik putih pada permukaan daun akibat tusukan ovipositor imago pada saat makan dan meletakkan telur. Gejala lainnya adalah garis putih yang meliuk-Iiuk pada permukaan atas dan bawah daun yang disebabkan oleh aktivitas makan larva. Akibat kerusakan tersebut dapat menurunkan produksi kentang sebesar 65\% (Rauf, 1999) sampai 78\% (Supartha, 1998) di Jawa Barat, sementara di Bali sekitar 60\%-70\% permusimtanampadatahun 1998/1999 di kawasan Pancasari dan Kembangmertha (Supartha, 2002).

Pengendalian secara kimiawi sudah tidak efektif, sebab imagonya telah resisten terhadap insektisida dan hal tersebut telah diketahui sejak 10 tahun yang lalu di Peru (Raman, 1988; Raman dan RadclifFe, 1992)

Pengendalian hayati adalah cara terpenting yang dilakukan dalam usaha mengatur populasi hama tersebut di lapang. Cara tersebut telah banyak dilakukan dan terbukti efektif menurunkan populasi L. huidobrensis (Supartha et al., 1999). Namun dalam perkembangannya cara tersebut mengalami nambatan karena adanya variasi karakteristik biologis dari agen hayati seperti siklus hidup, kemampuan beradaptasi, keperidian dan nisbah kelamin (sex ratio).

Supartha (2002) menyebutkan ada beberapa jenis parasitoid yang berasosiasi pada L. huidobrensis dan tiga diantaranya adalah Hemyptarsenus varicornis Girault (Eulophidae), Opius sp. (Braconidae) dan Gronotoma micromorpha (Eucoilidae).

Keadaan di alam menunjukkan bahwa H. varicornis merupakan parasitoid yang paling dominan di lapang baik pada daerah daiaran tinggi maupun dataran rendah. Parasitoid tersebut juga menyebar pada semua tanaman inang dengan kisaran parasitisasi sekitar $44 \%$ (Shepard et al, 1996; Rauf et al, 2000; Supartha, 
2003). Sementara itu Opius sp. penyebarannya terbatas di daerah dataran tinggi pada tanaman kentang dan seledri dengan tingkat parasitisasi sekitar 21,4\% (Supartha, 2003). Kedua jenis parasitoid tersebut populasinya melimpah di Bali (Supartha, 2002; 2003). G. micromorpha adalah jenis parasitoid lain yang bersifat thelytoki yaitu tidak membutuhkan pejantan dalam perkembangan hidupnya, namun demikian populasi parasitoìd tersebut sangat rendah di lapang. Sementara di daerah lain seperti Jawa Barat populasinya sangat melimpah.

Fenomena tersebut menunjukkan bahwa tidak semua jenis parasitoid mampu beradaptasi dengan baik pada tempat yang berbeda. Faktor intrinsik dan ekstrinsik serangga sangat mempengaruhi keberhasilan beradaptasi dengan lingkungannya. Keefektifan musuh alami dalam mengendalikan populasi hama dapat juga diukur dari daya predatisme atau parasitismenya. Untuk jenis parasitoid yang tidak mempunyai toleransi luas terhadap kisaran serangga inang juga mempunyai arti penting untuk pengendalian terutama pada saat populasi serangga inang rendah. Cara lain yang juga digunakan dalam beradaptasi untuk mendapatkan serangga inang dengan kondisi lingkungan yang layak bagi pertumbuhannya adalah penyesuaian biologis parasitoid bersangkutan terhadap kondisi serangga inang yang tersedia. Dengan demikian penelitian ini dilakukan untuk mengetahui respon biologis masing - masing parasitoid dalam memanfaatkan kondisi inang selama hidupnya sehingga dapat diketahui keefektifan masing - masing parasitojd sebagaipengendali hayati.

\section{BAHAJN DAN METODE}

Penelitian ini dilaksanakan di Laboratorium Ekologi dan Sistematika Serangga dan Rumah Kaca Jurusan Hama dan Penyakit Tumbuhan Fakultas Pertanian Universitas Udayana di Denpasar. Suhu harian rata-rata 29 0C - 33 0C dan kelembaban udara $69 \%$ - $79 \%$. Penelitian ini dilakukan selama empat bulan.

Rancangan percobaan yang digunakan dalam penelitian ini adalah Rancangan Acak Kelompok (RAK). Untuk mengetahui respon biologi masing - masing parasitoid digunakan jenis serangga inang yang tidak terparasit.
Perlakuan tersebut diulang sebanyak 10 kali.

Kacang merah (Vigna sinensis (L) Hassk)

digunakan sebagai tanaman inang. Jenis Liriomyza yang digunakan sebagai serangga inang adalah L. huidobrensis. Jenis parasitoid yang digunakan dalam penelitian ini adalah G. micromorpha, Opius sp., dan H. varicornis karena masing-masing parasitoid tersebut memiliki sifat yang khas. Kascing digunakan sebagai bahan campuran tanah untuk media tanam dengan perbandingan $1: 3$. Larutan madu $10 \%$ diberikan sebagai pakan tambahan dan untuk menjaga kebugaran serangga inang maupun parasitoid (Fonataba, 2004). Alat yang digunakan meliputi polybag, ajir bambu, tali rafia, kurungan $60 \mathrm{~cm} \times 60 \mathrm{~cm}$, kain batis, toples penetasan, jarum, mikroskop, cawan Petri, aspirator, pinset, dankapas.

Adapun parameter yang diamati dalam penelitian ini adalah menghitung jumiah parasitoid yang dihasilkan selama siklus hidup, nisbah kelamin, tingkat parasitisasi, lama hidup imago dan mortalitas masing - masing parasitoid, lama hidup imago, praviposisi, pascaoviposisi.

Uji Respon Biologis Ma sing-Ma sing Parasitoid Dalam Pemanfaatan Kondisi Inang Selama Hidupnya

Satu ekor imago betina G. micromorpha, satu pasang imago Opius sp. dan $\mathrm{H}$. varicornis yang baru menetas (berumur sama) di masukkan ke dalam kurungan berisi tanaman inang yang telah terinfeksi iarva L.huidobrensis instar-3. Tanaman dibiarkan selama 24 jam agar ketiga jenis parasitoid tersebut memerasit inang kemudian tanaman tersebut diganti dengan tanaman inang baru. Setelah 24 jam tanaman dipindah kedalam kurungan bam (terhitung sebagai perlakuan untuk HI) dan tanaman diganti dengan tanaman baru yang telah terinfestasi yang dibiarkan selama 24 jam (terhitung sebagai H2), demikian seterusnya hinggaharike-10. Tanaman dipanen 3 hsi, jumiah parasit yang muncu! pada perlakuan tiap hari, menggambarkan kemampuan parasit dalam berkompetisi dan memanfaatkan kondisi inang selama hidupnya, perlakuan ini diulang sebanyak 10 kali (Gambarl). 


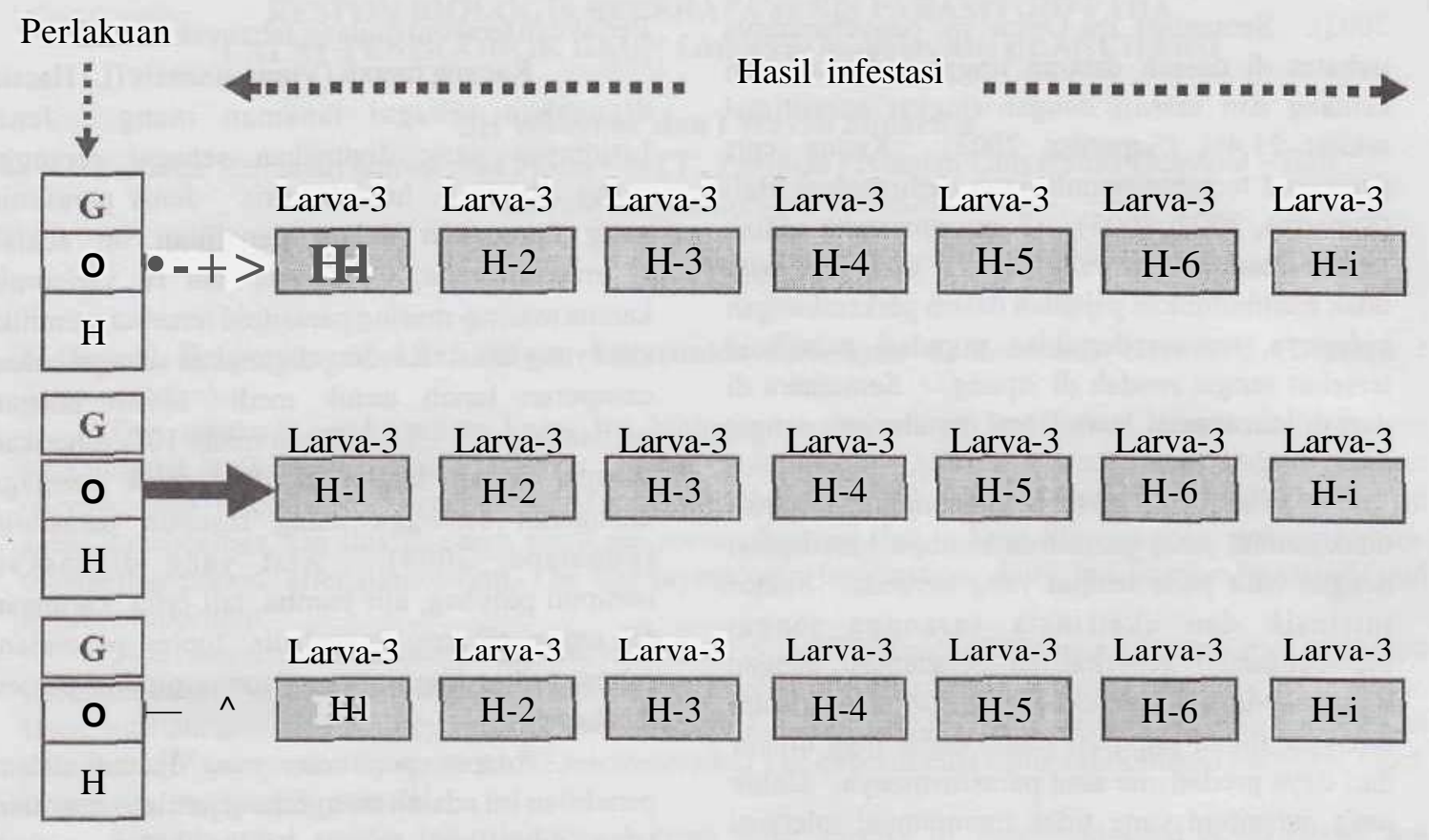

Keterangan :

$\mathrm{G}=$ G. Micromorpha

$\mathrm{H}=H$. varicarni $\quad \mathrm{Hi}=$ Hari ke- $\mathrm{i}$

$0=$ Optus sp.

Larva- $3^{\wedge}$ Larva L. Huidobrensis instar-3

Gambar 1. Bagan uji respon bïologis mas ing-mas ing parasitoid dalam pemanfaatan kondisi inang selama hidupnya

\section{HASIL DAN PEMBAHASAN}

\section{Respon Biologi Masing - Masing Parasitoid}

Tabel 1. Respon biologi Opius sp., G.micromorpha dan H.varicornis pada inang L.huidobrensis

\begin{tabular}{|c|c|c|c|c|}
\hline \multirow{2}{*}{ Parameter } & \multirow{2}{*}{$\begin{array}{c}\text { Jumlah } \\
\text { Sampel (N) }\end{array}$} & Opius sp & G.micromorpha & H.varicornis \\
\hline & & Rataan & Rataan & Rataan \\
\hline Lama Hidup Imago & 10 & $15,8 \quad 2,01 \mathrm{a}$ & $13,93,93 a$ & $9,5 \quad 2,01 b c$ \\
\hline Praoviposisi & 10 & $1,8 \quad 0,42 \mathrm{a}$ & $1,80,63 a$ & $0 \mathrm{Obc}$ \\
\hline Masa oviposisi & 10 & $13,18 \mathrm{a}$ & $12,50,17 \mathrm{a}$ & $141,76 a$ \\
\hline Pasca oviposisi & 10 & $0,80,63 b$ & $-, 1,90,32 \mathrm{a}$ & $0,3 \quad 0,48 b c$ \\
\hline Kcperidia harian & 10 & $4,7620,47 b$ & $1,1590,22 c$ & $12,322,62 \mathrm{a}$ \\
\hline Laju Peneluran & 10 & $5,320,49 b$ & $1,5530, \mathrm{I} 6 \mathrm{c}$ & $13,1772,95 \mathrm{a}$ \\
\hline Keperidian & 10 & $74,8 \quad 2,66 \mathrm{~b}$ & $16,56,6 c$ & $103,82,66 a$ \\
\hline Mortaiitas & 10 & $8,8 \quad 2,24 b$ & $5,1 \quad 4,12 b$ & $16,12,85 a$ \\
\hline Nisbah Kelamin Jantan & 5 & $1,190,98 \mathrm{a}$ & $00 \mathrm{~b}$ & $1,530,83 \mathrm{a}$ \\
\hline Nisbah Kelamin Betina & 5 & $2,793,07 a$ & $0,950, \mathrm{~S} 9 \mathrm{bc}$ & $4,643,23 a$ \\
\hline
\end{tabular}

Hasil penelitian ini memperlihatkan bahwa H.varicornis memiliki masa praoviposisi paling singkat dengan masa oviposisi paling lama jika dibandingkan dengan O.liriomyzae maupun G.micromorpha, selain itu H.varicornis juga memiliki masa pascaoviposisi yang paling rendah. Hal tersebut menandakan bahwa Mekanisme penerimaan serangga inang sebagai tempat perkembangbiakan parasitoid yang
Respon masing - masing parasitoid dapat dlihat pada tabel 1 berikut: bersifat endoparasit berbeda dengan mekanisme penerimaan serangga inang oleh parasitoid yang bersifat ektoparasit. (Begon, 1986) menyatakan bahwa penerimaan serangga inang adalah suatu proses diterimanya atau ditolaknya serangga inang sebagai tempat peletakan telur setelah terjadinya kontak. Proses tersebut dibagi dalam empat fase yaitu (a) kontak dan pemeriksaan, (b) penusukan dengan ovipositor, (c) pemasukan ovipositor dan, 
(d) peletakan telur. Keempat fase tersebut haras lengkap dan berurutan sehingga bila ada hambatan pada salah satu fase, proses penerimaan serangga inang dimulai lagi dari awal. Mekanisme tersebut yang raengakibatkan $G$. micromorpha ataupun $O$. liriomyzae sangat selektif untuk memilih serangga inang yang paling tepat untuk perkembangan keturunnya, sehingga dengan demikian baik $G$. micromorpha maupun $O$. liriomyzae tidak dapat memarasit serangga inang yang didalamnya terdapat parasitoid lain.

Sementara Menkenberg (1986) mengemukakan bahwa parasitoid yang bersifat ektoparasit melakukan tusukan pertama untuk pengenalan serangga inang, tusukan kedua untuk melemahkan serangga inang, tusukan ketiga untuk peletakan telur. $H$. varicornis merupakan parasitoid yang bersifat ektoparasit yang meletakkan satu telur pada bagian luar larva seragga inang setelah melakukan pelumpuhan. $H$. varicornis betina melakukan pelumpuhan tidak hanya untuk peletakan telur tetapi juga untuk. melakukan host-feeding. Pada peristiwa pelumpuhan maupun host-feeding, H. varicornis tidak pernah memperhatikan kondisi serangga inang secara intrinsik yaitu apakah pada serangga inang itu terdapat parasitoid lain atau tidak, sehingga dari peristiwa pelumpuhan maupun host-feeding dapat mengakibatkan kematian pada serangga inang maupun parasitoid yang terdapat pada serangga inang tersebut. Keadaan tersebut yang mengakibatkan $\mathrm{H}$. Varicornis lebih mampu memanfaatkan kondisi serangga inang yang telah terparasit oleh parasitoid lain dibandingkan dengan G. micromorpha dan O. liriomyzae. Namun demikian $H$. varicornis tidak melakukan hostfeeding dan peletakan telur pada serangga inang yang sama.

Gambar 2 memperlihatkan bahwa pada hari pertama H.varicornis telah mampu menghasilkan keturunan sebanyak 4,8 ekor sementara O.liriomyzae dan G.micromorpha mulai menghasilkan keturunan pada hari kedua (O.liriomyzae: 0,2 dan G.micromorpha : 0.3). Hal tersebut menjadikan $\mathrm{H}$,varicornis lebih unggul dibandingkan dengan kedua jenis parasitoid lainnya. H.varicornis mengalami puncak peneluran pada hari kelima (11,3), sedangkan O.liriomyzae pada hari ketujuh $(10,9)$ dan G.micromorpha masa puncak penelurannya tidak nampak.

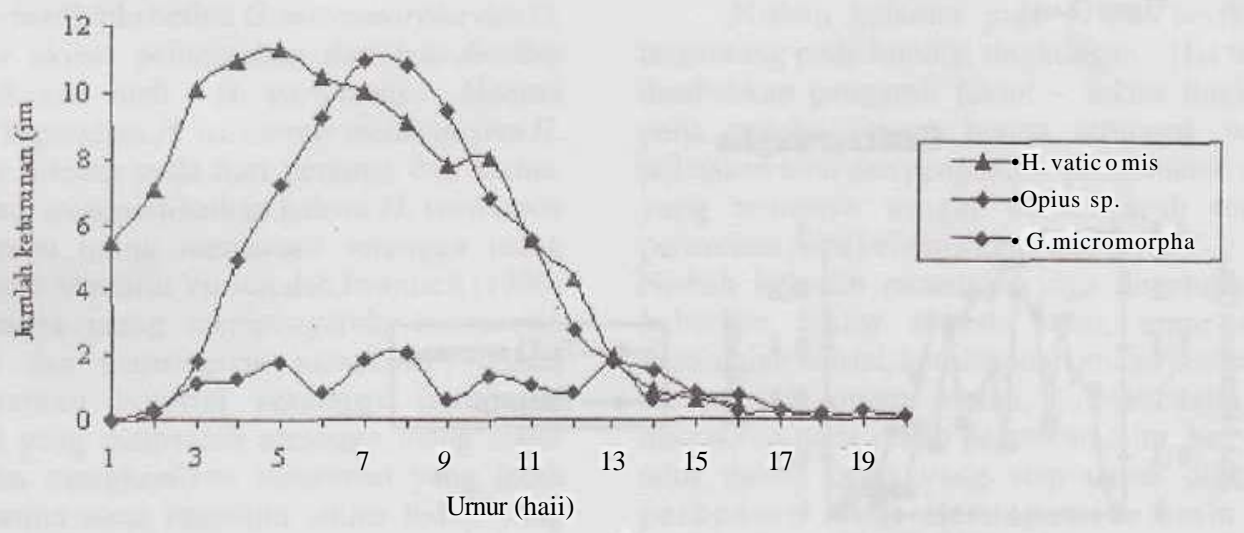

Gambar 2. Respon biologis beberapa jenis parasitoid

H.varicornis dapat menghasilkan jumlah imago yang paling baik pada hari ketiga sampai hari ketujuh, setelah hari ketujuh kemampuan H.varicornis berangsur - angsur akan menunm. Ketahanan atau sintasan pada H.varicornis paling baik terjadi pada had pertama sampai hari ke-I3 (Gambar 2). Jumlah imago yang dihasilkan oleh Opius sp. paling baik terjadi pada hari keenam sampai hari kesepuluh, sintasan Opius sp. paling baik terjadi pada hari pertama sampai ke-17 (Gambar 3). Jumlah imago yang dihasilkan oleh G.micromorpha tidak nampak mempengaruhi populasi serangga inang dengan rentang sintasan yang lebih pendek yaitu pada hari pertama sampai hari ketujuh (Gambar 3). 


\section{Qpinusp.}

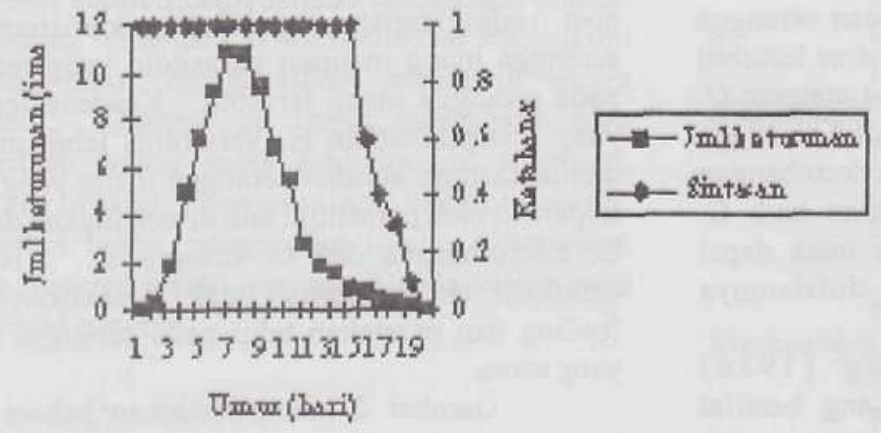

\section{Huariconis}

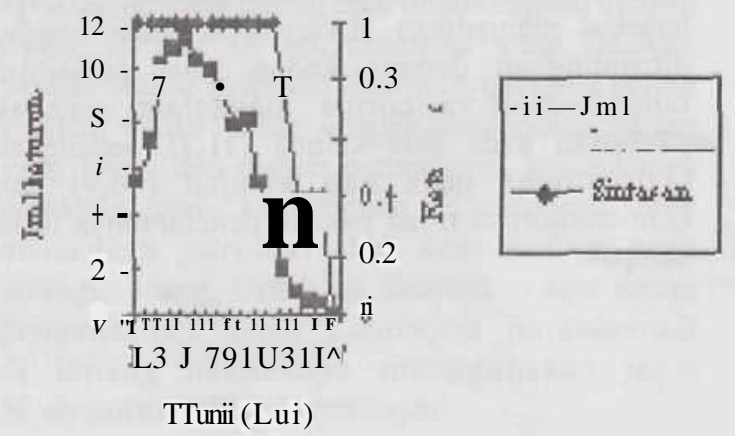

\section{Griucromoryha}

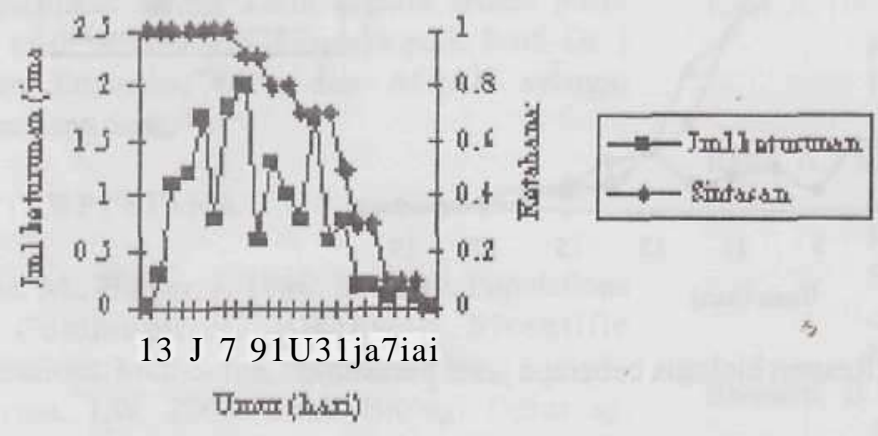

Gambar 3. Pola sintasan beberapa jenis parasitoid

Pada pengamatan perilaku diketahui bahwa $H$. varicornis mempunyai kemampuan untuk melakukan pelumpuhan dan host-feeding. Pelumpuhan atau paralisis dilakukan untuk melemahkan atau mengurangi keaktitan serangga inang agar telur $H$. varicornis yang diletakkan pada bagian luar tubuh serangga inang tidak terlepas akibat gerakan atau gesekan serangga inang dengan jaringan daun. Sementara hostfeeding dilakukan untuk mendapatkan makanan dengan cara menghisap cairan tubuh serangga inangnya, untuk parasitoid betina host-feeding sangat penting dilakukan untuk memenuhi kebutuhan protein guna memproduksi telur. Keunggulan lain yang dimiliki oleh $H$. varicornis adalah waktu yang diperlukan untuk pengenalan habitat, pencarian inang, penerimaan inang dan memarasit lebih cepat jika dibandingkan dengan G. micromorpha dan $O$. liriomyzae. Kondisi yang demikian menandakan bahwa $H$. varicornis mempunyai kemampuan yang baik untuk menyesuaikan diri dengan habitatnya dan 
mampu bereproduksi lebih cepat dari $G$. micromorpha dan $O$. liriomyzae. Selain itu $H$. varicornis tidak memiliki masa praoviposisi (Maryana, 2002) dan siklus hidup yang singkat (Sudiartha, 2002), sehingga $H$. varicornis dapat menghasilkan keturunan lebih awal dan lebih banyakjikadibandingkan dengan $G$. micromorpha dan $O$, liriomyzae. Mortalitas atau kegagalan telur menetas menjadi imago pada $G$. micromorpha dan $O$. liriomyzae disebabkan oleh adanya peristiwa pelumpuhan dan host-feeding yang dilakukan oleh H. varicornis. Keadaan tersebut dapat diketahui dari tingkat mortalitas tertinggi pada kedua jenis parasitoid tersebut terjadi pada saat $G$. micromorpha atau $O$. liriomyzae dilepas sebelum pelepasan $H$. varicornis. Pada situasi tersebut $H$. varicornis dapat menghasilkan tingkat keperidian yang tinggi yang tentunya akan diikuti oleh tingginya tingkat parasitisasi dibandingkan dengan G. micromorpha atau $O$, liriomyzae, hal tersebut dapat disebabkan karena $H$. varicornis dapat memilih dengan baik untuk serangga inang yang tepat untuk melakukan peletakan telur tanpa adanya gangguan dari parasitoid lain. Mortalitas yang terjadi pada $G$. micromorpha maupun $O$. liriomyzae selain mempengaruhi tingkat keperidian juga mempengaruhi jumlah proporsi betina. Hal tersebut disebabkan oleh terbunuhnya calon individu- inadividu betina $G$. micromorpha dan $O$. liriomyzae akibat pelumpuhan dan host-feeding yang dilakukan oleh $H$. varicornis. Namun demikian keperidian $H$. varicornis menurun jika $H$. varicornis dilepas pada had pertama dan kedua. Hal tersebut memperiihatkan bahwa $H$. varicornis lebih mampu untuk memarasit serangga inang instar lanjut. Menurut Vinson dan twantsch (1980) fase serangga inang mempengaruhi kesesuaian parasitoid dan kemampuan parasitoid dalam memanfaatkan kondisi serangga inangnya. Parasitoid yang memarasit serangga inang instar lanjut akan menghasilkan keturunan yang lebih banyak betina serta memiliki siklus hidup yang lebih pendek (Budiayasa, 2002).

Kesesuaian serangga inang merupakan faktor penentu dalam keberhasiian perkembangan parasitoid dari telur samapai menjadi imago. Kesesuaian tersebut tergantung pada : 1) kemampuan parasitoid untuk menghindari atau melawan sistem pertahanan serangga inang, 2) kompetisi dengan parasitoid lain, 3) kesesuaian makanan parasitoid. $H$. varicornis mampu memanfaatkan serangga inang selama hidupnya dan mempertahankan habitatnya dari parasitoid lain. Pada perlakuan kompetisi, keperidian dan tingkat parasitisasi pada $H$. varicornis mengalami peningkatan dua kali lipat dari keadaan normal atau tanpa kompetisi. Menurut Waseloh (1981) kegiatan berkompetisi dapat mempengaruhi peningkatan keperidian dan kebugaran parasitoid sebab adanya peristiwa memperebutkan serangga inang dari parasitoid lain, sehingga parasitoid cenderung lebih giat untuk mencari dan memarasit serangga inangnya. Sebaliknya apabila parasitoid tidak mempunyai kemampuan berkompetisi maka hal tersebut akan menurunkan tingkat keperidian dan daya predatismenya. Tingkat parasitisasi suatu jenis parasitoid sejalan dengan jumlah imago yang dihasilkannya yaitu semakin tinggi tingkat keperidian maka semakin tinggi pula tingkat parasitisasinya.

Musuh alami yang dinilai efektif memiliki ciri mempunyai potensi berkembangbiak tinggi yang dicirikan dengan keperidian (tingkat kelahiran) dan fertilitas (tingkat kesuburan) yang tinggi serta siklus hidup yang relatif pendek, dan mempunyai tingkat parasitisasi yang tinggi (DeBach, 1971).

Pada hasil penelitian yang dilakukan oleh Petitt dan Wietlisbach (1993) memperiihatkan bahwa parasitoid memarasit inang instar lanjut maka parasitoid akan menghasilkan masa perkembangan yang lebih singkat dengan nisbah kelaminyang bias betina.

Nisbah kelamin juga sangat berfluktuasi tergantung pada kondisi lingkungan. Hal tersebut disebabkan pengaruh faktor - faktor lingkungan pada prilaku imago betina termasuk perilaku peletakan telur dan pengaturan pengeiuaran sperma yang tentunya sangat berpengamh terhadap penentuan jenis kelamin keturunannya.

Nisbah kelamin parasitoid juga ditentukan oleh beberapa faktor seperti suhu, umur imago, kesesuaian nutrisi, kemampuan imago jantan untuk mengawini imago betina, jumlah telur yang diletakkan pada setiap peletakan telur, banyaknya telur dalam ovari yang siap untuk diletakkan, t perbedaan kecenderungan kelamin pada 'perkembangan poliembrionik, perbedaan mortalitas selama masa perkembangan, interval kawin seteiah imago muncul dari pupa terutama perbandingan telur yang diletakkan sebelum dan sesudah kawin, terlalu sering kawin, adanya perbedaan tanggap peletakan telur sesudah dan sebelum kawin, adanya unsur pemilihan tempat peletakan telur dan kecepatan peletakan telur. (Vinson dan Iwantsch, 1980). Perlakuan kompetisi yang dilakukan pada percobaan ini memperiihatkan pola kompetisi yang terbentuk antara H.varicornis, O.liriomyzae dan G.micromorpha. H.varicornis mengalami puncak peneluran pada hari keiima, pada saat 
tingkat peneluran H.varicornis mulai menurun, pada hari ketujuh O.liriomyzae mengalami puncak peneluran, sementara G. micromorpha mengalami tekanan untiik menghasilkan keturunan secara optimal. Keadaan ini dapat disebabkan oieh perbedaan waktu masa praoviposisi, oviposisi, pascaoviposisi, pengenalan habitat inang, pencarian inang, pengenalan inang, penerimaan inang maupun waktu memarasit pada ketiga jenis parasitoid tersebut.

\section{SIMPULAN}

Ffemiparsinus varicomis mevupakan jenis parasitoid yang mempunyai kemampuan sebagai agen hayati yang paling baik dibandingkan dengan Opius sp dan $G$. micromorpha yang ditandai dengan waktu oviposisi dan paca ovposisi paling singkat, siklus hidup pendek, keperidian harian yang tinggi dan nisbah betina tingi, kesemuanya didukung oleh kemampuan H.varicornis untk melakukan paralisis dan host-feeding pada serangga inang. Untuk itu disarankan agar dalam pengendalian hama Liriomyza huiduhrensis di lapang hendaknya menggunakan jenis $H$. vericornis sebagai agen bayati.

\section{UCAPAN TERIMA KASIH}

Pada kesempatan ini penults ingin mengucapkan terima kasih kepada semua pihak yang telah membantu khususnya pada Prof. Dr. I Wayan Supartha, MR, dan ACIAR sebagai penyandang dana.

\section{DAFTARPUSTAKA}

Begon. M., Harper, J. 1986. Ecology, Populations and Communities. Blackwell Sicentific Publications. Melbourne, Australia. 876p.

Budiyasa, I.W. 2002. Studi Biologi Opius sp. (Hymenoptera : Braconidae) pada Liriomyza huidobrensis (Blanchard) (Diptera : Agromyzidae). (TesisJ. Denpasar: Universitas Udayana. 51 hal

DeBach P. 1971. The Scope of Biological Control. In : DeBach P., editor. Biological Control of Insect Oests and Weed. London : Chapman and Hall, p 3 - 20.

Fonataba, Y.S. 2004. Studi Pembiakan Massal dan Pelepasan Parasitoid Hama Liriomyza spp. (Diptera : Aromyzidae), Gronotoma micromorpha (Hymenoptera : Eulolidae) pada Pertanaman Sayuran di Bali. (Tests). Denpasar : Universitas Udayana. 38 hal.

Maryana, N. 2002. Studies On Ecological Aspects Neochrysocharis formosa (Hymenoptera: Eulophidae) Attacking Liriomyza trifolii (Diptera : Agromyzidae). Fakuoka : University of Kyushu. Pp. 98-102.

Minkenberg, O.P.J.M., Van Lenteren, J.C. 1986. The Lifeminers Liriomyza trifolii and Liriomyza bryoniae (Diptera : Agromyzidae), Their Parasites and Their Host Plants Areview Agric. Wegeningan : University of Wegeningan. 86(2): 1 -50.

Petitt, F.L., Wietlisbach, D.O. 1993. Effect of Host Instar and Size on Parasitisation Effeciency and Life History Parameters of Opius dissitus. Entomol Exp. Appl. 66:227-236.

Raman, K.V. 1988. Integrated Insect Pest Management for Potatoes in Developing Countries. CIP Circular. Int. Potato Center (CIP), Lima, Peru. 16 $\mathrm{Cl}>$ : $1-8$.

Raman, K.V., Radcliffe, E.B. 1992. Pest Aspect of Potato Production. Part 2. Insect Pest. In P.M. Harris., editors. The Potato Crop. The scientific basis for environment. Chapman \& Hall. London. Pp. 476-506.

Rauf, A. 1999. Liriomyza: Datang Menantang PHT Kentang. Raker Perhimpunan Perlindungan Tanaman Indonesia. Cisania,BogorlO-12Maret. 16 hal.

Rauf, A., Shepard, B.M., Jhonson, M.W, 2000. Leafminer in Vegetables, Ornamental Plants and Weeds in Indonesia : Surveys of hosts crops, species A composition and parasitoids. Int.J.Pest Manag.46(4);4-7.

Shepard, B,M., Braunn, A., Rauf,A., Samsudin. 1996. Liriomyza huidobrensis Hama Pendatang Baru pada Sayuran. Warta PHTPalawijadanSayuranI(1):2-3.

Sudiartha, 1.P. 2002. Biodiversitas Parasitoid dan Peranannya Dalam Pengaturan Populasi Liriomyza huidobrensis (Blanchard) dan Liriomyza sativae (Blanchard : Agromyzidae) pada Pertanaman Kentang dan Tomat. (Skripsi). Denpasar : Universitas Udayana. 39 hal.

Supartha, I.W. 1998. Biomi Liriomyza huidobrensis (Blanchard) (Diptera; 
Agromyzidae pada Tanaman Kentang. (Disertasi) Bogor : Institut Pertanian Bogor. 146hal.

Supartha, I.W., Susila, I.W. Sunari, A.A.A.A.S., Bagus, I.G.N., Sutama. 1999. Penerapan Beberapa Komponen PHT terhadap Serangan Liriomyza huidobrensis (Blanchard) pada Pertanaman Kentang di Bali. Laporan Penelitian. Fakultas Pertanian UNUD dan Dinas Pertanian Tanaman Pangan PropensiBali. 51 hal.

Supartha, I. W. 2002. Pengembangan Pengendalian Hayati Liriomyza spp. pada Berbagai Tanaman Sayuran di Bali. Makalah Utama Seminar Pengembangan Pengendalian Hayati pada Tanaman Sayuran di Bali. 14 Januari 2002. BPTPHVU.Denpasar. 11 hal.

Supartha, I.W. 2003. Keragaman Fauna Parasitoid Liriomyza spp. (Dipter:
Agromyzidae) pada Tanaman Sayuran di Bali dan Lombok. Makalah Seminar Kongres Peerhimpunan Entomologi Indonesia dan Simposium Entomologi VI2003.Cipayung5-7Maret2003.

Vinson, S.B., Iwantsch, G.F. 1980. Host Suitability for Insect Parasitoid. Annu. Rev. Entomol25: 397-419.

Waseloh, R.M. 1981. Host Location by Parasitoid In : Norddlund DA, Jones R.L., Lewis,W.J. Editor. Semiochemical, Their Roie in Pest Control. New York ; Johs Wiley and Sons. P79-95.

Waterhous.D.F.,Norris. 1987. Biological Control: Pasific prospects. Inkata press. Melborn.Pp. 159-179.

Vinson, S.B., Iwantsch, G.F. 1980. Host Suitability for Insect Parasitoid. Annu. Rev. Entomol 25:397-419. 